\title{
Yield of corms of Acidanthera bicolor var. murielae perry depending on the date and depth of planting corms
}

\author{
Anna Kocira1*, Halina Laskowska², Sławomir Kocira ${ }^{3}$ \\ 1 Institute of Agricultural Sciences, State School of Higher Education in Chełm, Pocztowa 54, 22-100 Chełm, Poland \\ ${ }^{2}$ Institute of Ornamental Plants and Landscape Architecture, University of Life Sciences, Głęboka 28, 20-612 Lublin, Poland \\ ${ }^{3}$ Department of Machinery Exploitation and Production Process Management, University of Life Sciences, Głęboka 28, 20-612 Lublin, Poland
}

\begin{abstract}
The experiments were conducted in 2000-2002. Corms of Acidanthera bicolor var. murielae Perry were planted on four dates, every ten days: 19-20th of April, 29-30th of April, 8-9th of May, 18-19th of May, and at three different depths: 4, 8, and $12 \mathrm{~cm}$. At the end of the vegetation period, the plants were dug out and cormels obtained were dried, cleaned and calibrated by 8 sizes that included cormels of the following circumferences: below $4.0 \mathrm{~cm}, 4.1-6.0 \mathrm{~cm}, 6.1-8.0 \mathrm{~cm}, 8.1-10.0 \mathrm{~cm}$, $10.1-12.0 \mathrm{~cm}, 12.1-14.0 \mathrm{~cm}, 14.1-16.0$, and over $16.0 \mathrm{~cm}$. Then, the cormels were grouped into three sizes: I - cormels with a circumference of over $10.0 \mathrm{~cm}$; II - cormels of $10.0-8.1 \mathrm{~cm}$ in circumference; and III - cormels of $8.0-6.0 \mathrm{~cm}$ in circumference. The structure and weight of the total and marketable yield as well as further values of cormel circumference were determined. The marketable yield comprised cormels with a circumference of over $8 \mathrm{~cm}$, belonging to group I and II of the cormel size. It was found that planting corms in April increased the number of cormels in the total yield as well as the number and weight of marketable cormels. Planting corms at a depth of $12 \mathrm{~cm}$ increased the number and weight of cormels in the total yield as well as the weight of marketable cormels in comparison to the shallowest planting depth (4 cm). Planting corms on the 19-20th of April at a depth of $12 \mathrm{~cm}$ increased the percentage and weight of the largest cormels with a circumference of over $16 \mathrm{~cm}$ in comparison to planting them on the 18-19th of May at a depth of $4 \mathrm{~cm}$.
\end{abstract}

Keywords: Iridaceae; Acidanthera; planting methods; yield of cormels

\section{Introduction}

Acidanthera bicolor var. murielae Perry is more and more often used as a subtle accent in landscape arrangements, thanks to not only the beauty of its flowers, but also its delicate fragrance. This plant, classified in the family Iridaceae, is indigenous to the mountainous region of the East Africa and is included in the group of geophytes. Its above-ground part dries out and vanishes during drought and the corm allows the plant to survive under the ground. The plant forms oval cormels of 10-12 cm in circumference, covered with veined, brown scales formed from the leaf base. The cormel is formed by the thickening of the second internode of the stem above the cotyledon as a result of the previous year's growth of the plant. The following year, the replacement corm provides storage substances to the new shoot and shrivels, while forming adventitious cormels at the base. In our climate conditions, corms of Acidanthera should be dug out when the temperature falls below $7^{\circ} \mathrm{C}$ and then

* Corresponding author. Email: akocira@pwsz.chelm.pl

Handling Editor: Elżbieta Weryszko-Chmielewska stored indoor and protected against frost [1-3]. According to Krause [4], corms can be planted into the ground in the second half of April. Many authors have proved that planting corms and bulbs at different dates and depths is a factor determining the yield of this plant [5-9]. Therefore, it seems advisable to estimate the influence of the date and depth of planting corms on the yield of Acidanthera bicolor cormels.

\section{Material and methods}

The research was conducted in the years 2000-2002 at the Department of Ornamental Plants of the University of Life Sciences in Lublin. The experiment was established in a randomized block design in 5 replications. An area of $1 \mathrm{~m}^{2}$ was replication had. Thirty corms of Acidanthera bicolor var. murielae Perry, 8-9 cm in circumference, were planted per $1 \mathrm{~m}^{2}$ plot, in rows with spacing of $25 \mathrm{~cm}$. Each year, corms were bought from the same producer of flowers from the Netherlands. Three planting depths were used: 4, 8 and $12 \mathrm{~cm}$, and four planting dates, every 10 days: the $1 \mathrm{st}$ one on the 19-20th of April, the 2nd one on the 29-30th of April, the 3rd one on the 8-9th of May, and the 4th one 
on the 18-19th of May. The end of the vegetation period, that is, the moment when the plants were half-dried and the corms formed a brown covering scale, was observed on the following dates: 12th of September - 23rd of October 2000, 10-19th of October 2001, and 10-14th of October in 2002. At this stage, the plants were dug out and their above-ground part was cut at a height of $5 \mathrm{~cm}$ over the replacement corm. The obtained clones of corms were put into an open-work crate for two weeks. The dried cormels were cleaned and calibrated by 8 sizes: cormels with a circumference of less than $4.0 \mathrm{~cm}, 4.1-6.0 \mathrm{~cm}, 6.1-8.0 \mathrm{~cm}, 8.1-10.0 \mathrm{~cm}, 10.1-12.0 \mathrm{~cm}$, $12.1-14.0 \mathrm{~cm}, 14.1-16.0$, and over $16.0 \mathrm{~cm}$. According to the Polish Standard No. PN-92/R-67030, the corms were grouped into three sizes: I - cormels with a circumference of over $10.0 \mathrm{~cm}$; II $-10.0-8.1 \mathrm{~cm}$ in circumference; and III $-8.0-6.0 \mathrm{~cm}$ in circumference. The structure and weight of total and marketable yield as well as the successive circumferences of cormels were estimated. Cormels with a circumference of over $8 \mathrm{~cm}$, belonging to size group I or II, were classified as marketable yield. The results of the research were statistically analyzed by ANOVA (analysis of variance) using Statistica software. The results of the studied parameters were similar in all the years and therefore the analysis used the average for the years 2000-2002.

\section{Results}

The plants obtained from corms planted on the April dates produced the most cormels in the total yield (1171.8 and 1145.5 No. $\mathrm{m}^{-2}$, respectively; Tab. 1). Planting corms in May decreased the number of cormels (1048.9 and 1145.5 No. $\mathrm{m}^{-2}$, respectively). Analyzing the depth of corm planting, it was proved that the most cormels were produced by the plants obtained from corms planted the deepest, at $12 \mathrm{~cm}\left(1177.0\right.$ No. $\left.\mathrm{m}^{-2}\right)$, in comparison to planting corms at the depths of 4 and $8 \mathrm{~cm}$ (1016.5 and 1128.8 No. $\mathrm{m}^{-2}$, respectively).
It was found that the number of cormels in marketable yield (circumference over $8 \mathrm{~cm}$ ) depended on the date of planting corms. The least corms of this size were obtained from mother corms planted on the 18-19th of May (33.2 No. $\mathrm{m}^{-2}$ ). The other dates of planting corms were characterized by the quantity of cormels in marketable yield at a similar level (from 35.1 to 36.4 No. $\mathrm{m}^{-2}$ ). No influence of the depth of corm planting on the number of cormels in marketable yield was observed for the respective planting dates. It was found that a larger number of cormels in marketable yield was obtained when corms were planted on the 8-9th of May at a depth of $8 \mathrm{~cm}\left(36.9\right.$ No. $\left.\mathrm{m}^{-2}\right)$, in comparison to the last planting date of corms at a depth of 4 and $12 \mathrm{~cm}$ (32.5 and 32.7 No. $\mathrm{m}^{-2}$, respectively).

The largest weight of cormels in total yield was obtained when corms were planted on the 19-20th of April $\left(1218.5 \mathrm{~g} \mathrm{~m}^{-2}\right)$ in comparison to the other planting dates, that is 29-30th of April, 8-9th of May, and 18-19th of May (1178.9, 1031.3, and $773.8 \mathrm{~g} \mathrm{~m}^{-2}$, respectively; Tab. 2). Moreover, the highest weight of cormels was obtained in the case of the deepest planting depth $\left(1307.4 \mathrm{~g} \mathrm{~m}^{-2}\right)$. Planting corms at the deepest depth in April, that is, on the 29-30th and 19-20th, increased the weight of total cormel yield (1501.9 and $1488.1 \mathrm{~g} \mathrm{~m}^{-2}$, respectively). A definite decrease in the weight was observed with the most shallow planting of corms on the last date, i.e. on the $18-19$ th of May $\left(588.5 \mathrm{~g} \mathrm{~m}^{-2}\right)$.

The obtained results indicate that the date of planting corms determined the weight of marketable cormel yield (Tab. 2). Planting corms in April increased the weight of cormels in marketable yield (973.2 and $962.9 \mathrm{~g} \mathrm{~m}^{-2}$, respectively). The plants obtained from mother corms planted on the last date, 18-19th of May, were characterized by the lowest weight of cormels $\left(617.4 \mathrm{~g} \mathrm{~m}^{-2}\right)$. Planting corms at the depth of $12 \mathrm{~cm}$ increased the weight of cormels in marketable yield $\left(1110.6 \mathrm{~g} \mathrm{~m}^{-2}\right)$ in comparison to the depth of 4 and $8 \mathrm{~cm}$ (581.2 and $860.3 \mathrm{~g} \mathrm{~m}^{-2}$, respectively). It was observed that cormels of the largest weight were produced by the plants derived from corms that were planted in April at the depth of

Tab. 1 The influence of the date and depth of planting corms on the number of cormels in total and marketable yield of Acidanthera bicolor var. murielae Perry.

\begin{tabular}{|c|c|c|c|c|c|}
\hline Planting date & $\begin{array}{c}\text { Planting depth } \\
(\mathrm{cm})\end{array}$ & $\begin{array}{l}\text { Total yield } \\
\left(\text { No. } \text { m }^{-2}\right)\end{array}$ & Mean & $\begin{array}{c}\text { Marketable } \\
\text { yield }\left(\text { No }^{-2}\right)\end{array}$ & Mean \\
\hline 19-20 April & $\begin{array}{r}4 \\
8 \\
12\end{array}$ & $\begin{array}{l}1046.9 \mathrm{bcd} \\
1144.5 \mathrm{cde} \\
1245.2 \mathrm{e}\end{array}$ & $1145.5 \mathrm{~B}$ & $\begin{array}{l}34.5 \mathrm{ab} \\
36.4 \mathrm{ab} \\
34.4 \mathrm{ab}\end{array}$ & $35.1 \mathrm{~B}$ \\
\hline 29-30 April & $\begin{array}{r}4 \\
8 \\
12\end{array}$ & $\begin{array}{l}1107.4 \mathrm{bcd} \\
1237.7 \mathrm{e} \\
1170.1 \mathrm{de}\end{array}$ & $1171.8 \mathrm{~B}$ & $\begin{array}{l}34.3 \mathrm{ab} \\
35.1 \mathrm{ab} \\
36.0 \mathrm{ab}\end{array}$ & $35.2 \mathrm{~B}$ \\
\hline 8-9 May & $\begin{array}{r}4 \\
8 \\
12\end{array}$ & $\begin{array}{c}916.3 \mathrm{a} \\
1097.0 \mathrm{bcd} \\
1133.5 \mathrm{cde}\end{array}$ & $1048.9 \mathrm{~A}$ & $\begin{array}{l}36.1 \mathrm{ab} \\
36.9 \mathrm{~b} \\
36.1 \mathrm{ab}\end{array}$ & $36.4 \mathrm{~B}$ \\
\hline 18-19 May & $\begin{array}{r}4 \\
8 \\
12\end{array}$ & $\begin{array}{c}995.5 \mathrm{ab} \\
1035.3 \mathrm{abc} \\
1159.1 \mathrm{cde}\end{array}$ & $1063.3 \mathrm{~A}$ & $\begin{array}{l}32.5 \mathrm{a} \\
34.3 \mathrm{ab} \\
32.7 \mathrm{a}\end{array}$ & $33.2 \mathrm{~A}$ \\
\hline Mean & $\begin{array}{r}4 \\
8 \\
12\end{array}$ & $\begin{array}{l}1016.5 \mathrm{~A} \\
1128.6 \mathrm{~B} \\
1177.0 \mathrm{C}\end{array}$ & & $\begin{array}{l}34.4 \mathrm{~ns} \\
35.7 \mathrm{~ns} \\
34.8 \mathrm{~ns}\end{array}$ & \\
\hline
\end{tabular}

Means followed by the same letter do not differ significantly; ns - non-significant. 
Tab. 2 The influence of the date and depth of planting corms on the weight of total and marketable yield of cormels of Acidanthera bicolor var. murielae Perry.

\begin{tabular}{|c|c|c|c|c|c|}
\hline Planting date & $\begin{array}{l}\text { Planting depth } \\
\qquad(\mathrm{cm})\end{array}$ & $\begin{array}{l}\text { Total yield } \\
\qquad\left(\mathrm{g} \mathrm{m}^{-2}\right)\end{array}$ & Mean & $\begin{array}{c}\text { Marketable } \\
\text { yield }\left(\mathrm{g} \mathrm{m}^{-2}\right)\end{array}$ & Mean \\
\hline 19-20 April & $\begin{array}{r}4 \\
8 \\
12\end{array}$ & $\begin{array}{l}898.5 \mathrm{~cd} \\
1268.8 \mathrm{fg} \\
1488.1 \mathrm{~h}\end{array}$ & $1218.5 \mathrm{D}$ & $\begin{array}{c}678.3 \mathrm{bc} \\
988.4 \mathrm{e} \\
1252.9 \mathrm{~g}\end{array}$ & $973.2 \mathrm{C}$ \\
\hline 29-30 April & $\begin{array}{r}4 \\
8 \\
12\end{array}$ & $\begin{array}{l}855.8 \mathrm{bcd} \\
1179.0 \mathrm{f} \\
1501.9 \mathrm{~h}\end{array}$ & $1178.9 \mathrm{C}$ & $\begin{array}{r}635.0 \mathrm{~b} \\
966.5 \mathrm{e} \\
1287.2 \mathrm{~g}\end{array}$ & $962.9 \mathrm{C}$ \\
\hline 8-9 May & $\begin{array}{r}4 \\
8 \\
12\end{array}$ & $\begin{array}{r}748.7 \mathrm{~b} \\
1038.6 \mathrm{e} \\
1306.6 \mathrm{~g}\end{array}$ & $1031.3 \mathrm{~B}$ & $\begin{array}{r}575.2 \mathrm{~b} \\
842.8 \mathrm{~d} \\
1129.9 \mathrm{f}\end{array}$ & $849.3 \mathrm{~B}$ \\
\hline 18-19 May & $\begin{array}{r}4 \\
8 \\
12\end{array}$ & $\begin{array}{l}588.5 \mathrm{a} \\
800.1 \mathrm{bc} \\
932.8 \mathrm{de}\end{array}$ & $773.8 \mathrm{~A}$ & $\begin{array}{l}436.4 \mathrm{a} \\
643.3 \mathrm{~b} \\
772.5 \mathrm{~cd}\end{array}$ & $617.4 \mathrm{~A}$ \\
\hline Mean & $\begin{array}{r}4 \\
8 \\
12\end{array}$ & $\begin{array}{l}772.9 \mathrm{~A} \\
1071.6 \mathrm{~B} \\
1307.4 \mathrm{C}\end{array}$ & & $\begin{array}{r}581.2 \mathrm{~A} \\
860.3 \mathrm{~B} \\
1110.6 \mathrm{C}\end{array}$ & \\
\hline
\end{tabular}

Means followed by the same letter do not differ significantly; ns - non-significant.

$12 \mathrm{~cm}$ (1287.2 and $1252.9 \mathrm{~g} \mathrm{~m}^{-2}$, respectively). A significant decrease in the weight of cormels was noted for the last date of planting corms at the depth of $4 \mathrm{~cm}\left(436.4 \mathrm{~g} \mathrm{~m}^{-2}\right)$.

The date and depth of planting corms influenced the number of size I cormels (circumference over $10 \mathrm{~cm}$; Tab. 3). Planting corms on the 18-19th of May caused a decrease in the number of cormels with a circumference of over $10 \mathrm{~cm}$ $\left(29.0\right.$ No. $\left.\mathrm{m}^{-2}\right)$. The number of cormels obtained from the remaining dates of planting was higher, between 31.9 and 31.4 No. $\mathrm{m}^{-2}$. The most cormels with this circumference were obtained from plants planted at a depth of 12 and $8 \mathrm{~cm}\left(31.8\right.$ No. $\left.\mathrm{m}^{-2}\right)$ in comparison to those planted shallower $\left(29.4\right.$ No. $\left.\mathrm{m}^{-2}\right)$. It was shown that the most cormels of size I were obtained in the treatment with the deepest planting of corms on the 29-30th of April (32.7 No. mn comparison to the shallowest planting on the 18-19th and 8-9th of May (26.7 and 29.6 No. $\mathrm{m}^{-2}$, respectively). The date of planting corms influenced the weight of size I cormels. An increase in the weight of cormels was observed when the planting date was on the 19-20th and 29-30th of April (947.9 and $935.5 \mathrm{~g} \mathrm{~m}^{-2}$, respectively) in comparison to the planting date on the 18-19th and 8-9th of May (587.1 and $809.3 \mathrm{~g} \mathrm{~m}^{-2}$, respectively). The highest weight of cormels with a circumference of over $10 \mathrm{~cm}\left(1083.3 \mathrm{~g} \mathrm{~m}^{-2}\right)$ was observed for the planting depth of $12 \mathrm{~cm}$. The highest decrease in the weight of cormels was observed when corms were planted at a depth of $4 \mathrm{~cm}\left(547.6 \mathrm{~g} \mathrm{~m}^{-2}\right)$. Cormels of the highest weight were obtained from plants planted on the 29-30th

Tab. 3 The influence of the date and depth of planting corms on the number and weight of size I (circumference over $10 \mathrm{~cm}$ ) cormels of Acidanthera bicolor var. murielae Perry.

\begin{tabular}{|c|c|c|c|c|c|}
\hline Planting date & $\begin{array}{c}\text { Planting depth } \\
(\mathbf{c m})\end{array}$ & $\begin{array}{c}\text { Number of } \\
\text { cormels } \\
\left(\text { No. } \text { m }^{-2}\right)\end{array}$ & Mean & $\begin{array}{c}\text { Weight of } \\
\text { cormels }\left(\mathrm{g} \mathrm{m}^{-2}\right)\end{array}$ & Mean \\
\hline 19-20 April & $\begin{array}{r}4 \\
8 \\
12\end{array}$ & $\begin{array}{l}31.1 \mathrm{bc} \\
32.5 \mathrm{bc} \\
32.1 \mathrm{bc}\end{array}$ & $31.9 \mathrm{~B}$ & $\begin{array}{c}652.4 \mathrm{~cd} \\
956.8 \mathrm{f} \\
1234.6 \mathrm{~h}\end{array}$ & $947.9 \mathrm{C}$ \\
\hline 29-30 April & $\begin{array}{r}4 \\
8 \\
12\end{array}$ & $\begin{array}{l}30.3 \mathrm{bc} \\
32.3 \mathrm{bc} \\
32.7 \mathrm{c}\end{array}$ & $31.8 \mathrm{~B}$ & $\begin{array}{c}609.2 \mathrm{bc} \\
944.1 \mathrm{f} \\
1253.3 \mathrm{~h}\end{array}$ & $935.5 \mathrm{C}$ \\
\hline 8-9 May & $\begin{array}{r}4 \\
8 \\
12\end{array}$ & $\begin{array}{l}29.6 \mathrm{ab} \\
32.3 \mathrm{bc} \\
32.3 \mathrm{bc}\end{array}$ & $31.4 \mathrm{~B}$ & $\begin{array}{r}530.9 \mathrm{~b} \\
802.1 \mathrm{e} \\
1094.9 \mathrm{~g}\end{array}$ & 809.3 B \\
\hline 18-19 May & $\begin{array}{r}4 \\
8 \\
12\end{array}$ & $\begin{array}{l}26.7 \mathrm{a} \\
30.1 \mathrm{bc} \\
30.3 \mathrm{bc}\end{array}$ & $29.0 \mathrm{~A}$ & $\begin{array}{l}398.1 \mathrm{a} \\
612.8 \mathrm{bc} \\
750.3 \mathrm{de}\end{array}$ & $587.1 \mathrm{~A}$ \\
\hline Mean & $\begin{array}{r}4 \\
8 \\
12\end{array}$ & $\begin{array}{l}29.4 \mathrm{~A} \\
31.8 \mathrm{~B} \\
31.8 \mathrm{~B}\end{array}$ & & $\begin{array}{r}547.6 \mathrm{~A} \\
829.0 \mathrm{~B} \\
1083.3 \mathrm{C}\end{array}$ & \\
\hline
\end{tabular}

Means followed by the same letter do not differ significantly; ns - non-significant. 
of April and 19-20th of April at a depth of $12 \mathrm{~cm}$ (1253.3 and $1234.6 \mathrm{~g} \mathrm{~m}^{-2}$, respectively; Tab. 3). The lowest weight of cormels of the analyzed size was obtained for the shallowest planting depth and the last date $\left(398.1 \mathrm{~g} \mathrm{~m}^{-2}\right)$.

With increasing depth of corm planting, the percentage of cormels with a circumference over $16 \mathrm{~cm}$ increased (Fig. 1). However, delaying the date of planting corms resulted in a decrease in the number of cormels with the largest circumference at each depth of planting. A trend can be observed of an increased percentage of cormels with a circumference of $12-14 \mathrm{~cm}$ with the later date of planting. The largest share of cormels with a circumference of 10-12 cm was observed for the last date of planting corms.

The weight of cormels with the largest circumference decreased with the delayed date of planting corms (Fig. 2). In particular, the dates of planting with increasing depth of planting increased the weight of cormels with a circumference over $16 \mathrm{~cm}$. The exception is the last date of planting where the weight of cormels was at a similar level for the depth of both 8 and $12 \mathrm{~cm}$. There was an increasing trend in the weight of cormels with a circumference of $12-14 \mathrm{~cm}$ with a delay in the date of planting.

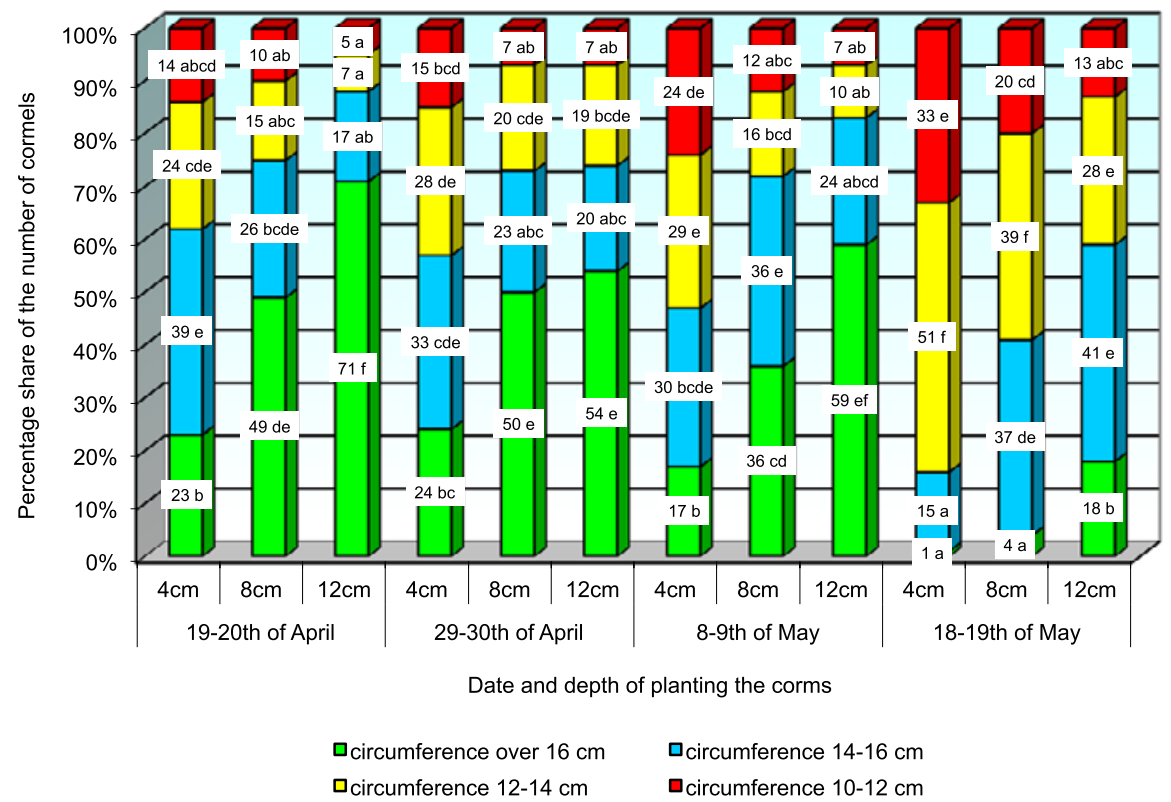

Fig. 1 The influence of the date and depth of planting corms on the percentage share of the number of cormels of different sizes in the yield of cormels with a circumference of over $10 \mathrm{~cm}$ (mean for 2000-2002; \%).

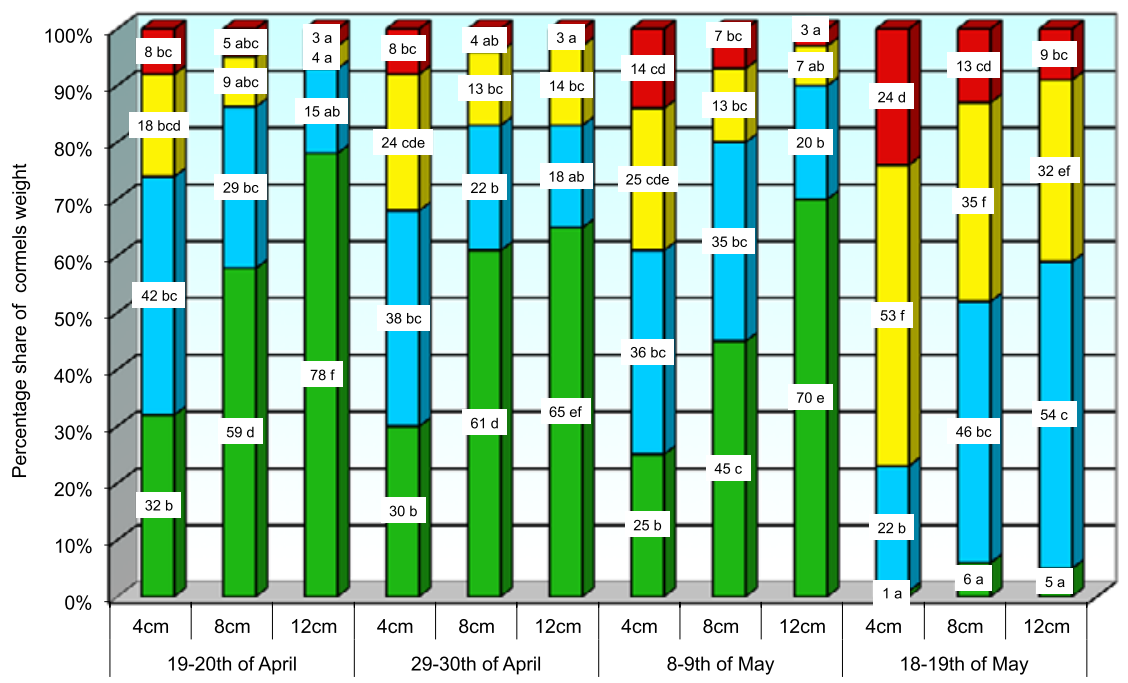

Date and depth of planting the corms

Fig. 2 The influence of the date and depth of planting corms on the percentage share of the weight of cormels of different sizes in the weight yield of cormels with a circumference of over $10 \mathrm{~cm}$ (mean for 2000-2002; \%). 
Tab. 4 The influence of the date and depth of planting corms on the number and weight of size II cormels (circumference $8-10 \mathrm{~cm}$ ) of Acidanthera bicolor var. murielae Perry.

\begin{tabular}{|c|c|c|c|c|c|}
\hline Planting date & $\begin{array}{l}\text { Planting depth } \\
(\mathrm{cm})\end{array}$ & $\begin{array}{c}\text { Number of } \\
\text { cormels } \\
\left(\text { No. } \mathbf{m}^{-2}\right)\end{array}$ & Mean & $\begin{array}{c}\text { Weight of } \\
\text { cormels }\left(\mathrm{g} \mathrm{m}^{-2}\right)\end{array}$ & Mean \\
\hline 19-20 April & $\begin{array}{r}4 \\
8 \\
12\end{array}$ & $\begin{array}{l}3.5 \mathrm{abc} \\
3.9 \mathrm{abc} \\
2.3 \mathrm{a}\end{array}$ & $3.2 \mathrm{~A}$ & $\begin{array}{l}26.0 \mathrm{~ns} \\
31.6 \mathrm{~ns} \\
18.4 \mathrm{~ns}\end{array}$ & $25.3 \mathrm{~A}$ \\
\hline 29-30 April & $\begin{array}{r}4 \\
8 \\
12\end{array}$ & $\begin{array}{l}4.0 \mathrm{abc} \\
2.8 \mathrm{ab} \\
3.3 \mathrm{ab}\end{array}$ & $3.4 \mathrm{~A}$ & $\begin{array}{l}25.9 \mathrm{~ns} \\
21.5 \mathrm{~ns} \\
34.0 \mathrm{~ns}\end{array}$ & $27.1 \mathrm{~A}$ \\
\hline 8-9 May & $\begin{array}{r}4 \\
8 \\
12\end{array}$ & $\begin{array}{l}6.5 \mathrm{c} \\
5.1 \mathrm{abc} \\
3.8 \mathrm{abc}\end{array}$ & $5.2 \mathrm{~B}$ & $\begin{array}{l}44.3 \mathrm{~ns} \\
40.7 \mathrm{~ns} \\
35.0 \mathrm{~ns}\end{array}$ & $40.0 \mathrm{~B}$ \\
\hline 18-19 May & $\begin{array}{r}4 \\
8 \\
12\end{array}$ & $\begin{array}{l}5.9 \mathrm{bc} \\
4.1 \mathrm{abc} \\
2.4 \mathrm{a}\end{array}$ & $4.1 \mathrm{AB}$ & $\begin{array}{l}38.3 \mathrm{~ns} \\
30.5 \mathrm{~ns} \\
22.2 \mathrm{~ns}\end{array}$ & $30.3 \mathrm{AB}$ \\
\hline Mean & $\begin{array}{r}4 \\
8 \\
12\end{array}$ & $\begin{array}{l}5.0 \mathrm{~B} \\
4.0 \mathrm{AB} \\
3.0 \mathrm{~A}\end{array}$ & & $\begin{array}{l}33.6 \mathrm{~ns} \\
31.1 \mathrm{~ns} \\
27.4 \mathrm{~ns}\end{array}$ & \\
\hline
\end{tabular}

Means followed by the same letter do not differ significantly; ns - non-significant.

The date and depth of planting corms influenced the number of cormels with an 8-10 cm circumference (Tab. 4). Planting corms on the 8-9th of May favored an increase in the number of cormels $\left(5.2 \mathrm{No} . \mathrm{m}^{-2}\right)$. The lowest number of cormels of this size was obtained from corms planted on the 19-20th and 29-30th of April (3.2 and 3.4 No. m ${ }^{-2}$, respectively). The most cormels were observed for the shallowest planting depth $\left(5.0\right.$ No. $\left.\mathrm{m}^{-2}\right)$ in comparison to the deepest planting (3.0 No. $\mathrm{m}^{-2}$ ). The most cormels were observed in the treatment where corms were planted the shallowest on the 8-9th of May $\left(6.5\right.$ No. $\left.\mathrm{m}^{-2}\right)$ in relation to their deepest planting on the 19-20th of April and 18-19th of May (2.3 and 2.4 No. $\mathrm{m}^{-2}$, respectively).
The date of planting corms influenced the weight of cormels with a circumference of $8-10 \mathrm{~cm}$ (Tab. 4). Cormels obtained from corms planted on the 8-9th of May $\left(40.0 \mathrm{~g} \mathrm{~m}^{-2}\right)$ had the largest weight in comparison with those planted on the 19-20th of April and the 29-30th of April (25.3 and $27.1 \mathrm{~g} \mathrm{~m}^{-2}$, respectively). A tendency was observed to increase the weight of cormels in the case of the shallowest planting depth on the 8-9th of May $\left(44.3 \mathrm{~g} \mathrm{~m}^{-2}\right)$.

The date and depth of planting corms determined the number of cormels with a 6-8 cm circumference (Tab. 5). The most cormels were observed for three planting dates: 19-20th and 29-30th of April as well as 8-9th of May (8.0, 7.8 and 7.6 No. $\mathrm{m}^{-2}$, respectively). A delay in the date of

Tab. 5 The influence of the date and depth of planting corms on the number and weight of cormels with a 6-8 cm circumference (size III) of Acidanthera bicolor var. murielae Perry.

\begin{tabular}{|c|c|c|c|c|c|}
\hline Planting date & $\begin{array}{c}\text { Planting depth } \\
(\mathbf{c m})\end{array}$ & $\begin{array}{c}\text { Number of } \\
\text { cormels } \\
\left(\text { No. } \text { m }^{-2}\right)\end{array}$ & Mean & $\begin{array}{c}\text { Weight of } \\
\text { cormels }\left(\mathrm{g} \mathrm{m}^{-2}\right)\end{array}$ & Mean \\
\hline 19-20 April & $\begin{array}{r}4 \\
8 \\
12\end{array}$ & $\begin{array}{l}8.6 \mathrm{~cd} \\
8.1 \mathrm{bcd} \\
7.1 \mathrm{bcd}\end{array}$ & $8.0 \mathrm{~B}$ & $\begin{array}{l}29.3 \mathrm{abc} \\
28.9 \mathrm{abc} \\
27.0 \mathrm{abc}\end{array}$ & $28.4 \mathrm{~B}$ \\
\hline 29-30 April & $\begin{array}{r}4 \\
8 \\
12\end{array}$ & $\begin{array}{l}8.5 \mathrm{~cd} \\
8.3 \mathrm{~cd} \\
6.5 \mathrm{a}-\mathrm{d}\end{array}$ & $7.8 \mathrm{~B}$ & $\begin{array}{l}28.8 \mathrm{abc} \\
31.8 \mathrm{bc} \\
27.2 \mathrm{abc}\end{array}$ & $29.3 \mathrm{~B}$ \\
\hline 8-9 May & $\begin{array}{r}4 \\
8 \\
12\end{array}$ & $\begin{array}{l}8.0 \mathrm{bcd} \\
9.1 \mathrm{~d} \\
5.6 \mathrm{a}-\mathrm{d}\end{array}$ & $7.6 \mathrm{~B}$ & $\begin{array}{l}25.6 \mathrm{abc} \\
33.5 \mathrm{c} \\
23.3 \mathrm{abc}\end{array}$ & $27.5 \mathrm{~B}$ \\
\hline 18-19 May & $\begin{array}{r}4 \\
8 \\
12\end{array}$ & $\begin{array}{l}4.7 \mathrm{abc} \\
4.2 \mathrm{ab} \\
3.1 \mathrm{a}\end{array}$ & $4.0 \mathrm{~A}$ & $\begin{array}{l}17.6 \mathrm{ab} \\
16.8 \mathrm{ab} \\
14.6 \mathrm{a}\end{array}$ & $16.3 \mathrm{~A}$ \\
\hline Mean & $\begin{array}{r}4 \\
8 \\
12\end{array}$ & $\begin{array}{l}7.5 \mathrm{~B} \\
7.5 \mathrm{~B} \\
5.6 \mathrm{~A}\end{array}$ & & $\begin{array}{l}25.3 \mathrm{~ns} \\
27.8 \mathrm{~ns} \\
23.1 \mathrm{~ns}\end{array}$ & \\
\hline
\end{tabular}

Means followed by the same letter do not differ significantly; ns - non-significant. 
planting until the 18-19th of May decreased the number of cormels of each size $\left(4.0 \mathrm{No} . \mathrm{m}^{-2}\right)$. Planting corms at a depth of 4 and $8 \mathrm{~cm}$ increased the number of cormels of individual size $\left(7.5 \mathrm{No} \mathrm{m}^{-2}\right)$ in comparison to the deepest planting $\left(5.6 \mathrm{No} . \mathrm{m}^{-2}\right.$ ). The most cormels of this size were obtained when corms were planted on the 8-9th of May at a depth of $8 \mathrm{~cm}\left(9.1\right.$ No. $\left.\mathrm{m}^{-2}\right)$ in comparison to all the depths of corm planting on the last date (4.7, 4.2 and 3.1 No. $\mathrm{m}^{-2}$, respectively).

The date of planting corms influenced the weight of cormels with a circumference of over 6-8 cm (Tab. 5). Planting corms in April and on the 8-9th of May favored an increase in the weight of cormels of the particular size (28.4, 29.3 and $27.5 \mathrm{~g} \mathrm{~m}^{-2}$, respectively). It was proved that planting corms on the last date significantly inhibited the weight of cormels $\left(16.3 \mathrm{~g} \mathrm{~m}^{-2}\right)$. The largest weight of this size was found when corms were planted on the 8-9th of May at a depth of $8 \mathrm{~cm}$ in comparison to all the planting depths on the last date.

The date and depth of planting corms determined the number and weight of cormels with a circumference below $6 \mathrm{~cm}$ (Tab. 6). The most cormels were obtained when corms were planted on the 29-30th and 19-20th of April (1128.8 and 1102.5 No. $\mathrm{m}^{-2}$, respectively). More cormels of this size were observed when the planting depth was $12 \mathrm{~cm}$ (1136.6 No. $\left.\mathrm{m}^{-2}\right)$ in comparison to the planting depth of 4 and $8 \mathrm{~cm}$ (974.7 No. $\mathrm{m}^{-2}$ ). Planting corms on the 19-20th of April increased the weight of cormels with a circumference below $6 \mathrm{~cm}\left(201.8 \mathrm{~g} \mathrm{~m}^{-2}\right)$ in comparison with all the planting dates.

\section{Discussion}

In the presented research, a relationship was found between the obtained yield of cormels and the date of planting corms. Planting corms on the 19-20th and 29-30th of April not only increased the number of cormels in total and marketable yield as well as the number of size I and III cormels, but it also resulted in an increase in the weight of cormels with a circumference over $10 \mathrm{~cm}$ (size I) and 6-8 cm (size III) in marketable yield. When corms were planted on the 19-20th of April, a higher number and weight of the smallest cormels (circumference below $6 \mathrm{~cm}$ ) in total yield were also obtained. Moreover, planting corms on the 8-9th of May increased the number of cormels with a circumference of over $10 \mathrm{~cm}, 8-10 \mathrm{~cm}$, and $6-8 \mathrm{~cm}$ as well as weight of cormels of sizes II and III. Definitely less cormels were obtained in total and marketable yields when the planting of corms was delayed until the 18-19th of May. Many studies have proved that earlier dates of planting corms or bulbs promote obtaining a higher total and marketable yield of cormels or daughter bulbs $[6,7,9,10]$. Also, the date of planting bulbs or corms influences the growth and development of the above-ground parts of the plant and thus the yield of their daughter bulbs and cormels, which has been confirmed by numerous studies [10-13]. Different climate conditions that are typical for India allow us to conclude that earlier planting of corms increased the number and weight of Gladiolus L. cormels [11-15]. Ahmad et al. [16] proved that earlier planting of Gladiolus corms (in the middle of February) in the climate conditions of Pakistan increased the weight of cormels. However, these authors found that delaying the date of planting corms till the beginning of April positively influenced the number of cormels. Laskowska et al. [10] showed that an earlier date of planting Allium aflatunense bulbs had a positive effect on obtaining a higher weight of daughter bulbs. Allium moly also positively responded to earlier planting of bulbs, since a higher number and weight of bulbs in total yield was obtained [17]. Islam and Haque [18], while conducting research on the dates of planting Gladiolus corms in the climate conditions of Bangladesh, proved that delaying planting until the 1st of July increased the number of cormels. However, the authors noted that

Tab. 6 The influence of the date and depth of planting corms on the number and weight of Acidanthera bicolor var. murielae Perry cormels with a circumference below $6 \mathrm{~cm}$.

\begin{tabular}{|c|c|c|c|c|c|}
\hline Planting date & $\begin{array}{c}\text { Planting depth } \\
(\mathbf{c m})\end{array}$ & $\begin{array}{c}\text { Number of } \\
\text { cormels } \\
\left(\text { No. m } \text { m }^{-2}\right)\end{array}$ & Mean & $\begin{array}{c}\text { Weight of } \\
\text { cormels }\left(\mathrm{g} \mathrm{m}^{-2}\right)\end{array}$ & Mean \\
\hline 19-20 April & $\begin{array}{r}4 \\
8 \\
12\end{array}$ & $\begin{array}{l}1003.8 \mathrm{bcd} \\
1099.9 \mathrm{cde} \\
1203.7 \mathrm{e}\end{array}$ & $1102.5 \mathrm{~B}$ & $\begin{array}{l}190.9 \mathrm{de} \\
206.3 \mathrm{e} \\
208.2 \mathrm{e}\end{array}$ & $201.8 \mathrm{D}$ \\
\hline 29-30 April & $\begin{array}{r}4 \\
8 \\
12\end{array}$ & $\begin{array}{l}1064.53 \mathrm{bcd} \\
1194.3 \mathrm{cde} \\
1127.6 \mathrm{de}\end{array}$ & $1128.8 \mathrm{~B}$ & $\begin{array}{l}191.9 \mathrm{de} \\
180.6 \mathrm{~cd} \\
187.5 \mathrm{de}\end{array}$ & $186.7 \mathrm{C}$ \\
\hline 8-9 May & $\begin{array}{r}4 \\
8 \\
12\end{array}$ & $\begin{array}{c}872.2 \mathrm{a} \\
1050.7 \mathrm{bcd} \\
1091.8 \mathrm{cde}\end{array}$ & $1004.9 \mathrm{~A}$ & $\begin{array}{l}147.9 \mathrm{ab} \\
162.3 \mathrm{bc} \\
153.5 \mathrm{ab}\end{array}$ & $154.6 \mathrm{~B}$ \\
\hline 18-19 May & $\begin{array}{r}4 \\
8 \\
12\end{array}$ & $\begin{array}{c}958.3 \mathrm{ab} \\
996.8 \mathrm{abc} \\
1123.3 \mathrm{cde}\end{array}$ & $1026.1 \mathrm{~A}$ & $\begin{array}{l}134.5 \mathrm{a} \\
140.0 \mathrm{ab} \\
145.0 \mathrm{ab}\end{array}$ & $139.8 \mathrm{~A}$ \\
\hline Mean & $\begin{array}{r}4 \\
8 \\
12\end{array}$ & $\begin{array}{r}974.7 \mathrm{~A} \\
1085.4 \mathrm{~B} \\
1136.6 \mathrm{C}\end{array}$ & & $\begin{array}{l}166.3 \mathrm{~ns} \\
172.3 \mathrm{~ns} \\
173.6 \mathrm{~ns}\end{array}$ & \\
\hline
\end{tabular}

Means followed by the same letter do not differ significantly; ns - non-significant. 
delaying the planting dates had a negative effect on the yields of plants. Later dates of planting decreased the size and quality of Scilla campanulata Ait. bulbs and caused a reduction in the weight of tulips bulbs, their marketable yield and delayed enlarging the daughter bulbs $[19,20]$. When the date of planting Gladiolus corms cultivated in India or Pakistan was delayed, a decrease in the number and weight of cormels was observed $[8,15,21]$. In the cultivation of Sparaxis tricolor (Curt) Ker. Gawl, it was found that planting corms in the first decade of May positively influenced the quality of cormels [5]. In the present experiment, the best effects were obtained, in terms of a high total and marketable yield as well as cormels of size I and the smallest ones, when corms were planted at adepth of $12 \mathrm{~cm}$. The effect of planting depth on the number of cormels in marketable yield as well as the weight of the smallest cormels and those of size II and III has not been proven. Moreover, planting corms at a depth of $8 \mathrm{~cm}$ positively influenced the number of cormels with a circumference of over $10 \mathrm{~cm}$ and $6-8 \mathrm{~cm}$. The shallowest planting of corms had a positive effect on the number of cormels of sizes II and III, but on the other hand, the plants obtained from corms planted at this depth responded with a decreased yield. Laskowska and Kocira [7] noted that planting corms at a depth of 8 and $12 \mathrm{~cm}$ increased the yield of cormels. According to the research of Incalcaterra [22], the optimal depth of planting Gladiolus cv. Peter Pears is $8 \mathrm{~cm}$. This author observed that increasing the depth of planting to 16 or $20 \mathrm{~cm}$ decreased the yields of plants. Maitra and Roychowdhury [13] also confirmed that planting corms of Gladiolus cv. Sylvia at a depth of $8 \mathrm{~cm}$ favored producing more replacement cormels of higher weight, but planting at a depth of $2 \mathrm{~cm}$ resulted in the plants producing more cormels. Peanav et al. [23] proved that planting Gladiolus corms at a depth of $10 \mathrm{~cm}$ had a more positive effect on its yields than planting them at a depth of $5 \mathrm{~cm}$. In a study conducted on Sparaxis tricolor (Curt) Ker. Gawl, it was proven that shallow planting of corms $(4 \mathrm{~cm})$ increased the yields of plants and resulted in producing large cormels [24]. Similar conclusions were made by Lee et al. [25] in their study on the yield of Freesia refracta cv. Anthene. The shallowest planting of Ornithogalum sandersiae Bak. bulbs $(5 \mathrm{~cm})$ positively influenced the yield and quality of daughter

\section{Acknowledgments}

Research supported by the Ministry of Science and Higher Education of Poland as part of the statutory activities of the Department of Ornamental Plants and Landscape Architecture, University of Life Sciences in Lublin.

\section{Authors' contributions}

The following declarations about authors' contributions to the research have been made: concept of the study: HL; field research: AK, SK; data analyses: AK, SK; references: AK, HL; writing the manuscript: AK, SK.

\section{Competing interests}

No competing interests have been declared.

\section{References}

1. Grabowska B, Krause J, Mynett K. Uprawa cebulowych i bulwiastych roślin ozdobnych. Warszawa: PWRiL; 1987.

2. Philips R, Rix M. Bulbs. London: Pan Books Ltd; 1981. bulbs [26]. A higher yield of bulbs of Fritillaria thunbergii cv. Chungbuk was observed when the bulbs were planted at a depth of 3 and $5 \mathrm{~cm}$ [27].

The planting depth of bulbs and corms affects the growth and development of plants, and especially their yield. Hagiladi et al. [28] showed that too deep planting of bulbs and corms provide worse conditions for plant growth and development. Delayed emergence and a reduced percentage of emerging plants were found for such plants. During the growth of these plants, a decrease in the number of developing shoots, leaves and flowering stems was observed, which results in a decrease in the number of daughter bulbs and corms as well as their fresh and dry weights. Planting the bulbs or corms of geophytes at the optimal depth had a positive effect on obtaining the highest yield of daughter bulbs or cormels [28]. In the present experiment, it was observed that planting corms on the 19-20th of April at a depth of $12 \mathrm{~cm}$ positively influenced the size of cormels. The biggest percentage of the number and weight of cormels with a circumference of over $16 \mathrm{~cm}$ in the yield of cormels of over $10 \mathrm{~cm}$ was observed in such case. The smallest percentage of the number and weight of cormels of this size was obtained when corms were planted on the 18-19th of May at a depth of $4 \mathrm{~cm}$.

\section{Conclusions}

Planting corms on the 19-20th and 29-30th of April increases the number of cormels in total yield as well as the number and weight of marketable cormels. On the other hand, planting corms on the 29-30th of April favors obtaining the highest weight of cormels in total yield.

The deepest planting of corms $(12 \mathrm{~cm})$ increases the number and weight of cormels in total yield and the weight of marketable cormels in comparison to planting them at a depth of $4 \mathrm{~cm}$.

The deeper planting of corms had an effect on producing more cormels that were characterized by a higher weight of the biggest size (circumference over $16 \mathrm{~cm}$ ).

The shallower planting increased the number of cormels of sizes II and III.

3. Szweykowska A, Szweykowski J. Botanika morfologia. Warszawa: Wyd. Naukowe PWN; 2003.

4. Krause J. Kwitnące cebule. Warszawa: Polski Związek Działkowców Krajowa Rada; 1992.

5. Kapczyńska A, Piskornik M, Klimek A. Wpływ terminu sadzenia bulw sparaksisu trójbarwnego [Sparaxis tricolor (Curt.) Ker Gawl.] w gruncie na jakość i plon kwiatów oraz bulw. Zesz Probl Post Nauk Roln. 2003;491:141-149.

6. Laskowska $H$. The influence of planting dates and leaf fertilization on yield of Scilla sibirica bulbs. Acta Hort. 1992;325:401-407.

7. Laskowska H, Kocira A. The effect of corm planting date and depth on Acidanthera bicolor Hochst. cormel yield. Folia Hortic. 2004;16(1):147-152.

8. Suneetha S, Vasanthakumar K. Influence of planting dates and cultivars on the performance of gladiolus under Kerala conditions. South Indian Horticulture. 1997;45(3-4):139-142. 
9. Maggio A, D'-Andria R, Morelli G. Irrigation of gladioli in hilly areas. Colture Protette 1993;22(12):63-69.

10. Laskowska H, Pogroszewska E, Durlak W, Kozak D. The effect of bulb planting time and type of mulch on the yield of Allium aflatunense B. Fedtsch. Acta Agrobot. 2012;65(4):117-122. http://dx.doi.org/10.5586/ aa.2012.028

11. Kalasareddi PT, Reddy BS, Patil SR, Patil PR, Kulkarni BS. Effect of time of planting on the performance of two cultivars of gladiolus. II. Flowering, flower quality and vase and field life. Adv Agric Res India. 1997;8:45-51.

12. Maitra S, Roychowdhury N. Effect of time and depth of planting on growth, development, flowering, corm and cormlet production of gladiolus (Gladiolus grandiflorus) cv. Sylvia. Hort J. 1999;12(2):83-90.

13. Misra RL. Residual effect of previous planting seasons on growth and flowering of gladiolus in the following growing season. Ann Agric Res. 1997;18(2):222-224.

14. Bagde MS, Golliwar VJ, Yadgirwar BM, Wankhede MN. Effect of planting dates on flower quality and yield parameters of gladiolus. Journal of Soils and Crops. 2009;19(2):351-354

15. Shiva KN, Dadlani NK. Effect of planting time on gladiolus under plastic greenhouse and open field conditions. Floriculture research trend in India. Proceedings of the national symposium on Indian floriculture in the new millennium, Lal-Bagh, Bangalore, 25-27 February 2002. p. 251-252.

16. Ahmad I, Khattak AM, Ara N, Noor-ul-Amin. Effect of planting dates on the growth of gladiolus corms in Peshawar. Sarhad J Agric. 2011;27(2):195-199.

17. Hetman J, Laskowska H, Durlak W. The influence of selected factors on the yield of Allium moly L. bulbs. Acta Sci Pol Hortorum Cultus. 2007;6(2):23-27.

18. Islam MS, Haque AFME. Performance of gladiolus under protected cultivation in the rainy season. Bangladesh J Agric Res. 2011;36(2):285-290. http://dx.doi.org/10.3329/bjar.v36i2.9256

19. Laskowska H. Plonowanie cebulicy dzwonkowatej (Scilla campanulata Ait.) w zależności od terminu sadzenia. II Ogólnopolskie Sympozjum "Nowe rośliny i technologie w ogrodnictwie", Poznań 17-19 września 1996; 2: 380-382.

20. Le Nard M. Effects of bulbs planting date on growth of tulip 'Don Quichotte' under mild winter conditions. Acta Hortic. 2002;570:153-156

21. Zubair M, Ayub G, Rab A, Amin N, Ahmad M, Ara N. Preflowering growth of gladiolus in response to staggered planting. Pak J Bot. 2013;45(4):1329-1338.
22. Incalcaterra G. Effects of planting depth and density on gladiolus corm production. Colture Protette. 1992;21(2):83-94.

23. Peanav R, Jitendra K, Mukesh K. Response of Ga3, plant spacing and planting depth on growth, flowering and corm production in gladiolus. J Ornam Hort. 2005;8(1):41-44.

24. Kapczyńska A. Optymalizacja produkcji i trwałość kwiatów ciętych Sparaxis tricolor hybrid [PhD thesis]. Kraków; 2001.

25. Lee JJ, Jeong JS, Kim DK, Kwon SW, Kim JC. Effect of planting depth on the growth and flowering in summer cultivation of cut freesia. J Korean Soc Hort Sci. 1997;38(1):77-80.

26. Kariuki W. Effect of planting depth on growth and flowering of Ornithogalum saundersiae Bak. Acta Hort. 2003;624:217-221.

27. Choi IS, Park JS, Cho JT, Son SY, Lee SS, Choi KS, et al. Effect of planting depth on quality and yield in Fritillaria thunbergii Miquel. J Indust Crop Sci. 1997;39(2):1-4.

28. Hagiladi A, Umiel N, Ozeri Y, Elyasi R, Abramsky S, Levy A, et al. The effect of planting depth on emergence and development of some geophytic plants. Acta Hort. 1992;325:131-138.

\section{Plonowanie acidantery dwubarwnej (Acidanthera bicolor var. murielae Perry) w zależności od terminu i głębokości sadzenia bulw}

\section{Streszczenie}

Doświadczenie przeprowadzono w latach 2000-2002. Bulwy Acidanthera bicolor var. murielae Perry sadzono w czterech terminach, w odstepach 10 dniowych: 19-20 kwietnia, 29-30 kwietnia, 8-9 maja i 18-19 maja stosując trzy głębokości sadzenia: 4, 8 i $12 \mathrm{~cm}$. Pod koniec okresu wegetacji rośliny wykopano, a uzyskane bulwy potomne osuszono, oczyszczono i kalibrowano na osiem wielkości tj. bulwy o obwodzie powyżej 16, 14-16, 12-14, $10-12,8-10,6-8,4-6$ i poniżej $4 \mathrm{~cm}$. Następnie podzielono je na trzy wielkości: I - bulwy o obwodzie powyżej $10 \mathrm{~cm}$, II - o obwodzie $10-8 \mathrm{~cm}$ i III - o obwodzie 8-6 cm. Określono strukturę i masę plonu ogólnego, handlowego i kolejnych wielkości obwodu bulw. Za plon handlowy przyjęto bulwy o obwodzie powyżej $8 \mathrm{~cm}$, należące do I i II wielkości bulw. Stwierdzono, że sadzenie bulw w terminach kwietniowych powoduje zwiększenie liczby bulw plonu ogólnego oraz liczby i masy bulw handlowych. Najgłębsze sadzenie bulw $(12 \mathrm{~cm})$ wpływa na zwiększenie liczby i masy bulw potomnych w plonie ogólnym oraz masy bulw handlowych w porównaniu do najpłytszego ich sadzenia $(4 \mathrm{~cm})$. Sadzenie bulw 19-20 kwietnia na głębokości $12 \mathrm{~cm}$ zwiększyło procentowy udział liczby i masy bulw największych tj. o obwodzie powyżej $16 \mathrm{~cm}$ w porównaniu do sadzenia ich 18-19 maja na głębokości $4 \mathrm{~cm}$. 